medRxiv preprint doi: https://doi.org/10.1101/2021.06.03.21258299; this version posted June 7, 2021. The copyright holder for this preprint

(which was not certified by peer review) is the author/funder, who has granted medRxiv a license to display the preprint in perpetuity.

All rights reserved. No reuse allowed without permission.

\title{
SARS-CoV-2 Seroprevalence Among Firefighters in Los Angeles, California
}

June 3, 2021

Karen Mulligan, Sol Price School of Public Policy and Leonard D. Schaffer Center for Health Policy \& Economics, University of Southern California, Los Angeles, USA

Anders H. Berg, Department of Pathology, Cedars-Sinai Medical Center, Los Angeles, USA

Marc Eckstein, Los Angeles Fire Department, Los Angeles, USA

Acacia Hori, University of Southern California, Los Angeles, USA

Anna Rodriguez, Sol Price School of Public Policy and Leonard D. Schaffer Center for Health Policy \& Economics, University of Southern California, Los Angeles, USA

Omar Toubat, University of Southern California, Los Angeles, USA

Neeraj Sood, Sol Price School of Public Policy and Leonard D. Schaffer Center for Health

Policy \& Economics, University of Southern California, Los Angeles, USA

Corresponding Author: Neeraj Sood

Verna and Peter Dauterive Hall, University of Southern California, 635 Downey Way, Los

Angeles, CA 90089; email: nsood@healthpolicy.usc.edu; P: 213-821-7949

Word Count: 1441

Keywords: SARS-CoV-2, Covid-19, seroprevalence, first responders 
medRxiv preprint doi: https://doi.org/10.1101/2021.06.03.21258299; this version posted June 7, 2021. The copyright holder for this preprint (which was not certified by peer review) is the author/funder, who has granted medRxiv a license to display the preprint in perpetuity.

\begin{abstract}
Objective

We estimate the seroprevalence of SARS-CoV-2 antibodies among firefighters in the Los Angeles, California fire department in October 2020 and compare demographic and contextual factors for seropositivity.
\end{abstract}

\title{
Methods
}

We conducted a serologic survey of firefighters in Los Angeles, California, USA, in October 2020. Individuals were classified as seropositive for SARS-CoV-2 if they tested positive for immunoglobulin $\mathrm{G}$, immunoglobulin $\mathrm{M}$, or both. We compared demographic and contextual factors for seropositivity.

\section{Results}

Of 713 participants, $8.9 \%$ tested positive for SARS-CoV-2 antibodies. Seropositivity was not associated with gender, age, or race/ethnicity. Furthermore, firefighters who worked in zip codes with lower income or higher share of minority population did not have higher rates of SARSCoV-2 infection. Seropositivity was highest among firefighters who reported working in the vicinity of Los Angeles International Airport, which had a known outbreak in July 2020.

\section{Conclusions}

Seroprevalence among firefighters was no higher than seroprevalence in the general population, suggesting that workplace safety protocols, such as access to PPE and testing, can mitigate increased risk of infection at work. Workplace safety protocols for firefighters also eliminated differences in disease burden by geography and race/ethnicity observed in the general population. 
medRxiv preprint doi: https://doi.org/10.1101/2021.06.03.21258299; this version posted June 7, 2021. The copyright holder for this preprint (which was not certified by peer review) is the author/funder, who has granted medRxiv a license to display the preprint in perpetuity.

All rights reserved. No reuse allowed without permission.

\section{INTRODUCTION}

First responders-including firefighters-have been working throughout the pandemic, which increases the likelihood of contracting severe acute respiratory syndrome coronavirus 2 (SARSCoV-2). While we may expect higher exposure to lead to higher rates of infectivity among first responders relative to the general population, preventive measures such as using personal protective equipment (PPE), conducting workplace screening, or implementing protocols to minimize exposure to infected patients may mitigate the increased risk of contracting SARSCoV-2 among first responders. Measuring seroprevalence of SARS-CoV-2 among first responders will improve our understanding of risk and transmission in front line worker populations.

Several studies have estimated seroprevalence in firefighter populations during the first six months of the pandemic in 2020. On the lower end, seroprevalence estimates ranged from $1.1 \%$ and $1.5 \%$ in Rochester (May) and Arizona (April/May), respectively.[1,2] In May/June seroprevalence was $5.4 \%$ in Cleveland $6.9 \%$ in Detroit.[3,4] In a single fire department located at the epicenter of an outbreak in South Florida, seroprevalence was 8.9\% in April.[5] Across all published studies, seroprevalence was highest among New York City firefighters: $22.5 \%$ in MayJuly.[6] Although it has been demonstrated that healthcare workers with high levels of patient contact experience greater odds of seropositivity than the general population or other public service employees,[4,7] seroprevalence among first responders or firefighters do not appear to significantly deviate from community estimates.[1,2,6]

In this study we conducted a serologic survey to estimate the prevalence of SARS-CoV-2 antibodies among firefighters in the Los Angeles Fire Department (LAFD) and tested for associations between seroprevalence and individual characteristics. 
medRxiv preprint doi: https://doi.org/10.1101/2021.06.03.21258299; this version posted June 7, 2021. The copyright holder for this preprint

(which was not certified by peer review) is the author/funder, who has granted medRxiv a license to display the preprint in perpetuity.

All rights reserved. No reuse allowed without permission.

\section{METHODS}

\section{Study design}

This is a prospective cohort study of firefighters employed by LAFD conducted in partnership between the University of Southern California, the LA County Department of Public Health, LAFD, Gauss Surgical, and Cedars Sinai Medical Center. Firefighters were invited to complete a questionnaire and received polymerase chain reaction (PCR) and antibody tests. This study was approved by the Los Angeles (LA) County Department of Public Health Institutional Review Board. Written informed consent was obtained from all study participants.

\section{Study participants and data}

An estimated 3,000 firefighters actively employed by LAFD were eligible for study participation. Participants were recruited through an employee intranet between July and October 2020. Participant onboarding was performed through a proprietary web- and mobile-based application developed by Gauss Surgical (Menlo Park, CA.) Onboarding involved describing study aims and methods to the participant, consenting the participant to complete PCR and antibody tests, and scheduling test dates. Data on participant age, sex, race/ethnicity, workplace location, symptoms, hospitalizations, patterns of PPE use, and PCR-confirmed SARS-CoV-2 infection history were collected through electronic surveys (Qualtrics International Inc., Seattle, WA).

\section{PCR and antibody testing}

PCR and antibody testing occurred between October 20 and 28, 2020. Participants who selfreported symptoms on a COVID-19 symptom screener on the test day were excluded from the study $(\mathrm{N}=4)$. PCR tests were performed on oropharyngeal specimens self-collected by 
medRxiv preprint doi: https://doi.org/10.1101/2021.06.03.21258299; this version posted June 7, 2021. The copyright holder for this preprint (which was not certified by peer review) is the author/funder, who has granted medRxiv a license to display the preprint in perpetuity.

All rights reserved. No reuse allowed without permission.

participants under study staff observation. RT-PCR was conducted against E and S mRNA transcripts at Cedars-Sinai Medical Center Department of Pathology (Los Angeles, CA.) For seroprevalence assessments, certified phlebotomists collected approximately 5 milliliters of venous blood from each participant. SARS-CoV-2-specific immunoglobulin M (IgM) and immunoglobulin $\mathrm{G}$ ( $\mathrm{IgG}$ ) antibodies were measured using the Abbott Architect instrument (Abbott Laboratories, Chicago, IL.) Manufacturer recommended signal-to-cutoff (S/CO) ratios of $>1.4$ and $>1.0$ were used as thresholds for seropositivity for IgG and IgM antibodies, respectively.

\section{Statistical analysis}

Participants were defined as seropositive if they had IgG, IgM, or both types of antibodies. Descriptive statistics for survey responses were summarized for the study cohort. We tested for differences in seropositivity by participant characteristics using two-sided tests and a significance level of $\mathrm{p}<0.05$. We also performed secondary analyses, including multivariable logistic regression and testing for differences in firefighter seroprevalence by contextual characteristics of workplace zip codes. We conducted sensitivity analysis using a modified S/CO threshold based on results from a validation study.[8] Results for the secondary and sensitivity analyses are presented in the Appendix. All statistical analyses were performed using Stata (StataCorp LLC, College Station, TX).

\section{RESULTS}

713 out of 715 firefighters who participated in the study had valid serologic data. Survey respondents had similar demographics to the overall population of LAFD. We limited our analysis sample to the 686 participants with no missing values for survey questions. Among the 
medRxiv preprint doi: https://doi.org/10.1101/2021.06.03.21258299; this version posted June 7, 2021. The copyright holder for this preprint (which was not certified by peer review) is the author/funder, who has granted medRxiv a license to display the preprint in perpetuity.

All rights reserved. No reuse allowed without permission.

firefighters that participated in the study and had non-missing data for survey questions, 61 $(8.9 \%)$ tested positive for either IgG, IgM, or both types of antibodies (Table 1). Approximately $14 \%$ of our respondents reported that they have not received a previous PCR test and $7.0 \%$ of respondents who reported not receiving a PCR test were antibody positive. Additional undiagnosed cases occurred among those who received a previous PCR test and got a negative result, with estimated seroprevalence of $3.2 \%$.

Gender, race, and age were not statistically significant predictors of seropositivity. Seropositivity was lower among females (odds ratio $(\mathrm{OR})=0.48,95 \% \mathrm{CI}=0.17-1.3$ ), but the difference between men and women was not statistically significant. Seroprevalence was not statistically different across race or ethnicity, but point estimates were highest among nonHispanic Asian participants $(\mathrm{OR}=1.82,95 \% \mathrm{CI}=0.78-4.2)$. We found no statistical differences in seroprevalence by age, but the point estimate was lowest among firefighters aged over 60 years $(\mathrm{OR}=0.85,95 \% \mathrm{CI}=0.16-4.42)$. Seroprevalence was highest $(31.3 \%(\mathrm{OR}=4.98,95 \% \mathrm{CI}=1.67-$ 14.9) among participants who reported working in the zip code containing the Los Angeles International Airport (LAX).

Table 1. SARS-CoV-2 seropositivity and association with individual characteristics among firefighters in Los Angeles, CA, USA

\begin{tabular}{|l|c|c|c|}
\hline Characteristics & No. $(\%)$ & $\begin{array}{c}\text { \% Seropositive } \\
{[95 \% \mathrm{CI}]}\end{array}$ & P-value \\
\hline Total & $686(100.0)$ & $8.9[6.8,11.0]$ & \\
\hline Age group (years) & $93(13.6)$ & $6.5[1.4,11.5]$ & \multirow{2}{*}{0.612} \\
\hline $18-29$ & $287(41.8)$ & $10.1[6.6,13.6]$ & \\
\hline $30-44$ & $270(39.4)$ & $8.9[5.5,12.3]$ & \\
\hline $45-60$ & $36(5.2)$ & $5.6[-1.9,13.1]$ & \multirow{2}{*}{0.132} \\
\hline$\geq 60$ & \multicolumn{3}{|c|}{} \\
\hline Gender & $83(12.1)$ & $4.8[0.2,9.4]$ & \\
\hline Female & $601(87.6)$ & $9.5[7.1,11.8]$ & \\
\hline Male & $2(0.3)$ & $0.0[\mathrm{n} / \mathrm{a}]$ & \\
\hline Non-Binary/Other &
\end{tabular}


medRxiv preprint doi: https://doi.org/10.1101/2021.06.03.21258299; this version posted June 7, 2021. The copyright holder for this preprint (which was not certified by peer review) is the author/funder, who has granted medRxiv a license to display the preprint in perpetuity. All rights reserved. No reuse allowed without permission.

\begin{tabular}{|c|c|c|c|}
\hline \multicolumn{3}{|l|}{ Race/ethnicity } & \\
\hline Non-Hispanic White & $357(52.0)$ & $7.3[4.6,10.0]$ & \multirow[t]{5}{*}{0.582} \\
\hline Non-Hispanic Black & $46(6.7)$ & $8.7[0.5,16.8]$ & \\
\hline Non-Hispanic Asian & $64(9.3)$ & $12.5[4.4,20.6]$ & \\
\hline Hispanic & $197(28.7)$ & $10.7[6.4,15.0]$ & \\
\hline Other/Mixed Race & $22(3.2)$ & $9.1[-2.9,21.1]$ & \\
\hline \multicolumn{3}{|c|}{ Ever had a Covid test (PCR)? } & \\
\hline No & $100(14.6)$ & $7.0[2.0,12.0]$ & \multirow[t]{4}{*}{$<0.001$} \\
\hline Yes, tested negative & $529(77.1)$ & $3.2[1.7,4.7]$ & \\
\hline Yes, tested positive & $52(7.6)$ & $71.2[58.8,83.5]$ & \\
\hline $\begin{array}{l}\text { Don't know or yes and } \\
\text { don't know test result }\end{array}$ & $5(0.7)$ & $0.0[\mathrm{n} / \mathrm{a}]$ & \\
\hline \multicolumn{3}{|c|}{ Experienced Covid symptoms since start of pandemic? } & \\
\hline No & $396(57.7)$ & $5.6[3.3,7.8]$ & \multirow[t]{2}{*}{$<0.001$} \\
\hline Yes & $290(42.3)$ & $13.4[9.5,17.4]$ & \\
\hline \multicolumn{3}{|c|}{ Experienced Covid symptoms in past 2 weeks? } & \multirow{3}{*}{0.004} \\
\hline No & $627(91.4)$ & $7.8[5.7,9.9]$ & \\
\hline Yes & $59(8.6)$ & $20.3[10.1,30.6]$ & \\
\hline \multicolumn{3}{|c|}{ Respondent thought it was likely they have had Covid-19 } & \\
\hline No & $543(79.2)$ & $3.5[2.0,5.0]$ & \multirow[t]{2}{*}{$<0.001$} \\
\hline Yes & $143(20.8)$ & $29.4[21.9,36.8]$ & \\
\hline \multicolumn{3}{|c|}{ Respondent likely had contact with anyone with known or suspected Covid-19 } & \multirow{3}{*}{0.005} \\
\hline No & $306(44.6)$ & $5.6[3.0,8.1]$ & \\
\hline Yes & $380(55.4)$ & $11.6[8.4,14.8]$ & \\
\hline \multicolumn{3}{|c|}{ 'Respondent works in LAX zip code } & \multirow{3}{*}{0.010} \\
\hline No & $615(97.5)$ & $8.3[6.1,10.4]$ & \\
\hline Yes & $16(2.5)$ & $31.3[17.4,45.1]$ & \\
\hline
\end{tabular}

Notes: Serologic survey conducted in October 2020. ${ }^{\dagger}$ Only $\mathrm{N}=631$ have valid zip code data

\section{DISCUSSION}

SARS-CoV-2 seroprevalence was 8.9\% in LAFD in October 2020. This estimate is 1 to 3 percentage points higher compared with estimates from other firefighter populations taken earlier in the pandemic (excluding NYC.) Cumulative incidence in our sample could be as high as $11.1 \%$ if we include participants who were not seropositive but received a positive PCR test (i.e., those who likely had SARS-CoV-2 but no longer have antibodies) in our calculations. While firefighters have higher risk of contracting SARS-CoV-2 due to the nature of their work, 
medRxiv preprint doi: https://doi.org/10.1101/2021.06.03.21258299; this version posted June 7, 2021. The copyright holder for this preprint (which was not certified by peer review) is the author/funder, who has granted medRxiv a license to display the preprint in perpetuity.

All rights reserved. No reuse allowed without permission.

seroprevalence in our sample is comparable to that in the general LA population during the same timeframe (15\%.)[9,10]

We found no evidence that firefighter demographics were associated with increased risk of seropositivity. The relatively small sample size in our study and corresponding low power for statistical tests provides one possible explanation for this result. Alternatively, lack of demographic differences in seropositivity may reflect uniform implementation of SARS-CoV-2 workplace protocols by LAFD such as wearing N95 masks, goggles, and gloves for all EMS incidents as well as putting masks on patients at time of first contact.[11] Analysis of contextual factors potentially supports this explanation: firefighters who work in zip codes that were disproportionately impacted by SARS-CoV-2 (i.e.,those with lower median income or a higher share of non-white, non-Hispanic residents[12]) did not have higher seroprevalence rates.

LAFD firefighters-including those who are asymptomatic-have had open access to PCR testing, which includes four sites located at fire stations throughout LA. Despite this, approximately $14 \%$ of our respondents (including $10 \%$ of those who reported experiencing symptoms during the pandemic) reported that they have not received a PCR test. Consequently, potential SARSCoV-2 cases went undiagnosed: $7.0 \%$ of respondents who reported not receiving a PCR test were antibody positive. Additional undiagnosed cases occurred among those who received PCR tests and got a negative result, with estimated seroprevalence of $3.2 \%$. This suggests that even workplaces that have relatively easy access to PCR testing may benefit from more systematic testing to identify asymptomatic or mildly symptomatic infections and limit workplace exposure.

This work should be viewed in light of its limitations. Our sample was self-selected, and accounted for approximately $24 \%$ of the full LAFD employee population. Participation may have been influenced by prior testing results, household exposure, or worker availability. 
medRxiv preprint doi: https://doi.org/10.1101/2021.06.03.21258299; this version posted June 7, 2021. The copyright holder for this preprint (which was not certified by peer review) is the author/funder, who has granted medRxiv a license to display the preprint in perpetuity.

All rights reserved. No reuse allowed without permission.

Nevertheless, our sample demographics were representative of the overall LAFD population.

Second, we did not ask respondents questions about their home environment-such as the total number of residents or the size of their home-which could have influenced their exposure to SARS-CoV-2. Furthermore, our sample collection period occurred in the months following the first wave of the pandemic, yet prior to the substantial rise in SARS-CoV-2 cases in LA County and the US beginning in November 2020.[13] Despite this, our study provides seroprevalence estimates and factors associated with SARS-CoV-2 infection for a population that is both at high risk of coming in contact with SARS-CoV-2, but also follows strong workplace protection practices.

Between $8.9 \%$ and $11.0 \%$ of firefighters in LAFD were infected with SARS-CoV-2 depending on whether we adjustment for waning antibodies. We did not observe significant differences in seroprevalence by demographic factors. Furthermore, our results suggest workers in occupations that adhere to similar protection or mitigation workplace protocols are likely to experience similar rates of SARS-CoV-2 infection irrespective of workplace location.

Acknowledgements: None 
medRxiv preprint doi: https://doi.org/10.1101/2021.06.03.21258299; this version posted June 7, 2021. The copyright holder for this preprint

(which was not certified by peer review) is the author/funder, who has granted medRxiv a license to display the preprint in perpetuity.

All rights reserved. No reuse allowed without permission.

\section{REFERENCES}

1 McGuire SS, Klassen AB, Heywood J, et al. Prevalence of COVID-19 IgG Antibodies in a Cohort of Municipal First Responders. Prehosp Disaster Med 2021;36:131-4. doi:10.1017/S1049023X2000151X

2 Shukla V, Lau CSM, Towns M, et al. COVID-19 Exposure Among First Responders in Arizona. Journal of Occupational \& Environmental Medicine 2020;62:981-5. doi:10.1097/JOM.0000000000002027

3 Caban-Martinez AJ, Schaefer-Solle N, Santiago K, et al. Epidemiology of SARS-CoV-2 antibodies among firefighters/paramedics of a US fire department: a cross-sectional study. Occup Environ Med 2020;77:857-61. doi:10.1136/oemed-2020-106676

4 Akinbami LJ, Vuong N, Petersen LR, et al. SARS-CoV-2 Seroprevalence among Healthcare, First Response, and Public Safety Personnel, Detroit Metropolitan Area, Michigan, USA, May-June 2020. Emerg Infect Dis 2020;26:2863-71. doi:10.3201/eid2612.203764

5 Tarabichi Y, Watts B, Collins T, et al. SARS-CoV-2 Infection among Serially Tested Emergency Medical Services Workers. Prehospital Emergency Care 2021;25:39-45. doi:10.1080/10903127.2020.1831668

6 Sami S, Akinbami LJ, Petersen LR, et al. Prevalence of SARS-CoV-2 Antibodies in First Responders and Public Safety Personnel, New York City, New York, USA, May-July 2020. Emerg Infect Dis 2021;27:796-804. doi:10.3201/eid2703.204340

7 Galanis P, Vraka I, Fragkou D, et al. Seroprevalence of SARS-CoV-2 antibodies and associated factors in healthcare workers: a systematic review and meta-analysis. Journal of Hospital Infection 2021;108:120-34. doi:10.1016/j.jhin.2020.11.008

8 Toubat O, Anders H. Berg, Kimia Sobhani, et al. Manufacturer Signal-to-Cutoff Threshold Underestimates Cumulative Incidence of SARS-CoV-2 Infection: Evidence from the Los Angeles Firefighters Study. https://www.medrxiv.org/content/10.1101/2021.04.20.21255829v1

9 Horn AL, Jiang L, Washburn F, et al. Estimation of COVID-19 risk-stratified epidemiological parameters and policy implications for Los Angeles County through an integrated risk and stochastic epidemiological model. Infectious Diseases (except HIV/AIDS) 2020. doi:10.1101/2020.12.11.20209627

10 Belin T, Bertozzi A, Chaudhary N, et al. Projections of Hospital-based Healthcare Demand due to COVID-19 in Los Angeles County. 2021.

http://file.lacounty.gov/SDSInter/dhs/1101466_COVID19ProjectionPublicUpdateLewis01.13.21English.pdf

11 Los Angeles Fire Department. Covid-19 FAQ. https://www.lafd.org/covid-19-faq\#q5 
medRxiv preprint doi: https://doi.org/10.1101/2021.06.03.21258299; this version posted June 7, 2021. The copyright holder for this preprint

(which was not certified by peer review) is the author/funder, who has granted medRxiv a license to display the preprint in perpetuity.

All rights reserved. No reuse allowed without permission.

12 Los Angeles County Department of Public Health. Covid-19: Racial, Ethnic, and Socioeconomic Data \& Strategies Report. 2020.

http://publichealth.lacounty.gov/docs/RacialEthnicSocioeconomicDataCOVID19.pdf

13 Los Angeles County Department of Public Health. LA County COVID-19 Surveillance Dashboard. http://dashboard.publichealth.lacounty.gov/covid19_surveillance_dashboard/ 